\title{
Sharia Compliance dan Islamic Corporate Governance terhadap Dana Pihak Ketiga pada Bank Umum Syariah
}

\author{
Annisa Dzahabiyah', Umiyati2 ${ }^{*}$ \\ 1, 2 Universitas Islam Negeri Syarif Hidayatullah Jakarta

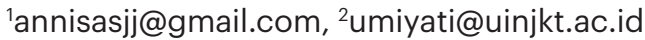 \\ ${ }^{*}$ Penulis korespondensi
}

\begin{abstract}
This study aims to analyze the effect of Sharia Compliance and Islamic Corporate Governance on Third Party Funds in Sharia Commercial Banks in Indonesia. The population in this study are Sharia Commercial Banks in Indonesia. Samples were selected using the purposive sampling method. The independent variables in this study are Islamic Income Ratio (IsIR), Proft Sharing Ratio (PSR), Zakat Performing Ratio (ZPR), and Islamic Corporate Governance (ICG). While the dependent variable is Third Party Funds (DPK). The analytical method used is panel data regression with e-views analysis tool 10. The results of this study indicate that the variable Profit Sharing Ratio (PSR) and Islamic Corporate Governance (ICG) significantly influence the Third Party Funds at Islamic Commercial Banks. While the Islamic Income Ratio (ISIR) and Zakat Performing Ratio (ZPR) variables do not significantly influence the Third Party Funds at Islamic Commercial Banks.
\end{abstract}

Keywords: Sharia Compliance, Islamic Corporate Governance, Third Party Funds, Islamic Banking

\begin{abstract}
Abstrak
Penelitian ini bertujuan untuk mengetahui pengaruh Sharia Compliance dan Islamic Corporate Governance terhadap Dana Pihak Ketiga pada Bank Umum Syariah di Indonesia. Populasi pada penelitian ini adalah Bank Umum Syariah di Indonesia. Sampel dipilih dengan menggunakan metode purposive sampling. Variabel independen pada penelitian ini adalah Islamic Income Ratio (IsIR), Profit Sharing Ratio (PSR), Zakat Performing Ratio (ZPR), dan Islamic Corporate Governance (ICG). Sedangkan variabel dependen adalah Dana Pihak Ketiga (DPK). Metode analisis yang digunakan adalah regresi data panel dengan alat analisis e-views 10. Hasil penelitian ini menunjukkan bahwa variabel Profit Sharing Ratio (PSR) dan Islamic Corporate Governance (ICG) berpengaruh secara signifikan terhadap Dana Pihak Ketiga pada Bank Umum Syariah. Sedangkan variabel Islamic Income Ratio (ISIR) dan Zakat Performing ratio (ZPR) tidak berpengaruh secara signifikan terhadap Dana Pihak Ketiga pada Bank Umum Syariah.
\end{abstract}

Kata Kunci: Sharia Compliance, Islamic Corporate Governance, Dana Pihak Ketiga, Bank Umum Syariah 


\section{PENDAHULUAN}

Menurut Falikhatun (2012) dalam Najib dan Rini (2016) menyebutkan bahwa semakin berkembangnya bank syariah berimplikasi pada semakin besarnya tantangan yang harus dihadapi oleh bank syariah tersebut, dimana tantangan terbesar adalah untuk mempertahankan citra dan nama baik di mata nasabah agar tetap menjaga kepercayaan serta loyalitas nasabah kepada bank syariah. Jika bank syariah mampu menjalankan operasionalnya dengan baik dan mampu mempertahankan kepercayaan nasabah, maka hal tersebut akan meningkatkan aset serta Dana Pihak Ketiga (DPK) pada bank syariah di Indonesia.

Pertumbuhan DPK menjadi salah satu faktor penting karena dana tersebut akan disalurkan oleh bank kepada calon nasabah pembiayaan untuk mengembangkan ekonomi masyarakat sehingga dapat mengembangkan sektor riil. Besarnya DPK mencerminkan tingkat kepercayaan masyarakat terhadap bank syariah (Fitrisia, 2016).

Berdasarkan data yang dipublikasikan oleh Badan Pusat Statistik (BPS) menyebutkan bahwa Dana Pihak Ketiga (DPK) perbankan syariah di Indonesia telah mengalami pertumbuhan 70,67\% yaitu sebesar Rp 371, 83 triliun pada akhir 2018 dibanding posisi tahun 2014. Pengumpulan dana perbankan syariah terbesar adalah dalam bentuk deposit mudharabah, yaitu mencapai Rp 213,79 triliun atau lebih dari separuh dari total DPK. Terhitung pada tahun 2018, DPK perbankan syariah mengalami pertumbuhan 11,03\% dari posisi akhir tahun sebelumnya. Untuk deposito mudharabah tumbuh 8,97\%, tabungan mudharabah meningkat 16,18\%, dan giro wadiah naik 8,48\% menjadi Rp 43,6 triliun.

Namun jumlah DPK pada bank umum syariah masih relatif rendah jika dibandingkan dengan bank umum konvensional. Dari laporan tahunan yang dikeluarkan oleh Otoritas Jasa Keuangan (OJK) memperlihatkan bahwa total DPK pada Bank Umum Konvensional mengalami kenaikan 9.08\% sebesar Rp 5.051 triliun ditahun 2017 dibandingkan dengan tahun sebelumnya yaitu Rp 4.630,4 triliun. Sementara itu ditahun yang sama Bank Umum Syariah hanya memperoleh DPK sebesar Rp 334,89 yang sebelumnya sebesar Rp 279,33 triliun ditahun 2016.

Salah satu penyebab dari permasalahan tersebut adalah masih kurangnya minat masyarakat Indonesia untuk menyimpan dananya di bank syariah. Padahal mayoritas penduduk Indonesia adalah beragama Islam. Namun hal tersebut tidak bisa menjadi jaminan, karena stigma atau pemikiran sebagian masyarakat yang masih menganggap bahwa bank syariah sama saja dengan bank konvensional. Oleh karena itu bank syariah harus mampu mempertahankan kepercayaan dan loyalitas nasabah dengan melaksanakan kepatuhan syariah yang berlaku (sharia compliance). Implementasi sharia governance merupakan salah satu indikator yang memberikan kontribusi terbesar untuk meningkatkan kepercayaan nasabah pada bank syariah karena ketaatan bank pada prinsip-prinsip syariah dalam menjalankan kegiatan operasionalnya. Namun apabila hal tersebut tidak diterapkan dengan baik maka akan menyebabkan munculnya berbagai risiko salah satunya yaitu pembiayaan bermasalah (Net Performing Financing) (Wardayati, 2011).

Selain meningkatnya pembiayaan bermasalah, pengungkapan kepatuhan syariah 
dalam laporan keuangan bank syariah di Indonesia masih relatif rendah. Hal tersebut dikarenakan kepercayaan akuntan dan manajer bank syariah terhadap penggunaan praktik pengungkapan kepatuhan syariah terhadap prinsip-prinsip syariah masih rendah. Sehingga menyebabkan terjadinya berbagai tindakan penipuan atau kecurangan yang dilakukan baik oleh pihak internal maupun eksternal bank yang bersangkutan. Oleh karena itu perlu diterapkan tata kelola yang sesuai dengan prinsip syariah (Islamic Corporate Governance). Hasil ini didukung oleh (Junusi, 2012) yang menyatakan bahwa rendahnya kepatuhan dengan prinsip syariah memberikan peluang terjadinya penipuan di bank syariah. Oleh karena itu, jaminan tentang pemenuhan kepatuhan syariah dari semua kegiatan mengelola dana nasabah oleh bank syariah sangat penting dalam kegiatan bisnis bank syariah.

Penerapan Islamic Corporate Governance (ICG) terbukti bisa meningkatkan citra atau reputasi serta kepercayaan masyarakat kepada bank syariah. Menurut Chapra, M.U. dan Ahmed, kegagalan bank syariah dalam melaksanakan penerapan prinsip syariah akan berdampak terhadap loyalitas nasabah, dimana nasabah akan berpaling atau pindah ke bank lain sebesar 85\%. Dengan demikian, penerapan sharia compliance dan penerapan Good Corporate Governance (GCG) menjadi sebuah keharusan dan kewajiban bagi perbankan syariah di Indonesia dalam upaya memperbaiki citra dan kepercayaan pada bank syariah. Hal tersebut juga didukung oleh Peraturan Bank Indonesia No. 11/33/PBI/2009 tentang pelaksanaan Good Corporate Governance (GCG) bagi Bank Umum Syariah dan Unit Usaha Syariah. Dewan Pengawasan Syariah memiliki fungsi untuk mengawasi dan memberikan nasihat kepada direksi agar operasional perbankan dapat sesuai dengan prinsip syariah. Untuk melihat apakah bank syariah telah memenuhi persyaratan kepatuhan syariah, maka dilakukan self-assesment secara berkala atas penerapan tata kelola perusahaan yang baik, sebagaimana diatur dalam peraturan otoritas jasa keuangan (Umiyati, 2020). Berdasarkan penelitian yang dilakukan oleh (Asrori, 2014) menyebutkan bahwa pelaksanaan Good Corporate Governance (GCG) dituangkan melalui pelaksanaan tugas dan tanggung jawab organ tata kelola Dewan Pengawas Syariah (DPS) yang bertujuan sebagai dewan penasihat dan pengawas.

Penelitian ini bertujuan untuk menganalisis pengaruh sharia compliance yang diukur dengan menggunakan rasio Islamic Income Ratio (IsIR), Profit Sharing Ratio (PSR), Zakat Performing Ratio (ZPR) dan Islamic Corporate Governance terhadap dana pihak ketiga pada bank umum syariah. Penelitian ini merupakan lanjutan dari penelitian Winny Widialoka (2016) dan Umiyati (2020). Pada penelitian Winny Widialoka (2016), peneliti menggunakan variabel dependen yang sama yaitu dana pihak ketiga. Sedangkan perbedaan penelitian ini dengan penelitian yang telah dilakukan terletak pada variabel independen, dimana Winny menggunakan variabel independen Sharia Compliance. Sedangkan pada penelitian ini variabel independen yang digunakan adalah Sharia Compliace dan Islamic Corporate Governance (ICG). Perbedaan lainnya yaitu pada sampel dan periode waktu yang digunakan dalam penelitian ini.

Persamaan penelitian ini dengan penelitian yang dilakukan (Umiyati, 2020) terletak pada variabel independen yang digunakan yaitu sharia compliance dan Islamic Corporate 
Governance. Perbedaannya terletak pada variabel dependen, dimana penelitian Umiyati menggunakan variabel dependen berupa kinerja keuangan sedangkan penelitian ini menggunakan variabel dana pihak ketiga.

Wardayati (2011) pada penelitiannya menggunakan variabel independen yaitu sharia compliance sama dengan penelitian ini. Untuk perbedaannya terletak pada variabel dependen, dimana penelitian Wardayati menggunakan variabel dependen berupa reputasi dan kepercayaan nasabah dengan metode kualitatif. Sedangkan penelitian ini menggunakan variabel dana pihak ketiga dengan metode kuantitatif. Pada penelitian yang dilakukan (Mulazid, 2016) terdapat persamaan pada variabel independen yang digunakan yaitu sharia compliance. Perbedaannya terletak pada jenis penelitian, penelitian ini menggunakan pendekatan kuantitatif sedangkan pada penelitian Mulazid menggunakan pendekatan kualitatif.

Islamic Income Ratio digunakan untuk mempresentasekan pendapatan Islam dari total seluruh pendapatan yang diterima bank. Berdasarkan penelitian yang dilakukan oleh Rifqy Muhammad, dkk (2019) menyatakan bahwa Islamic income ratio berpengaruh signifikan terhadap tindakan fraud pada bank syariah. Dengan adanya pengukuran menggunakan rasio tersebut maka tindakan kecurangan dapat diminimalisir sehingga mampu meningkatkan kepercayaan dan loyalitas nasabah terhadap bank syariah.

$\mathbf{H}_{\mathbf{1}}$ : Islamic income ratio berpengaruh secara signifikan terhadap dana pihak ketiga pada bank umum syariah di Indonesia.

Profit sharing ratio merupakan rasio yang membandingkan antara pembiayaan mudharabah dan musyarakah dengan seluruh total pembiayaan yang ada pada bank syariah tersebut. Oleh karena itu jika tingkat atau rasio bagi hasil mengalami peningkatan maka hal tersebut juga mendorong terjadinya peningkatan pada jumlah dana pihak ketiga. Penelitian yang dilakukan oleh Wardati dan Dina (2016) menyebutkan bahwa bagi hasil berpengaruh secara signifikan terhadap jumlah Dana Pihak Ketiga. Penelitian yang dilakukan Winny Widialoka, dkk (2016) juga menyatakan bahwa sharia compliance berpengaruh signifikan terhadap Dana Pihak Ketiga.

$\mathbf{H}_{2}$ : Profit sharing ratio berpengaruh secara signifikan terhadap dana pihak ketiga pada bank umum syariah di Indonesia.

Zakat Performing Ratio (ZPR) juga merupakan salah satu indikator dalam mengukur sharia compliance yang menjadi salah satu tujuan ekonomi islam. Menurut Hameed et al. (2004) rasio ini penting karena zakat merupakan perintah dalam ajaran islam. Adapun dalam standar AAOIFI, lembaga keuangan syariah diwajibkan membayar zakat dengan berbasis aset bersih. Namun di Indonesia sendiri perhitungan zakat berbasis pada laba sebelum pajak. Berdasarkan teori yang dikemukakan oleh (Raharjo, 2014) menyebutkan bahwa zakat merupakan salah satu tanggung jawab sosial yang harus dilaksanakan oleh setiap lembaga keuangan syariah yang dianggap cukup efektif sebagai promotion tools dan public relation. Sehingga dengan dipenuhinya penyaluran zakat oleh suatu bank syariah, 
maka hal tersebut dapat meningkatkan minat nasabah untuk menyimpan dananya pada bank syariah.

$\mathbf{H}_{3}$ : Zakat performing ratio berpengaruh secara signifikan terhadap dana pihak ketiga pada bank umum syariah di Indonesia.

Islamic Corporate Governance merupakan sistem tata kelola perusahaan berdasarkan prinsip-prinsip islam. Bank Umum Syariah diwajibkan secara berkala melakukan penilaian sendiri (self assessment) secara komprehensif terhadap tata kelola perusahaan. Penelitian yang dilakukan oleh (Winny Widialoka, 2016), (Junusi, 2012), dan (Wardayati, 2011) menyebutkan bahwa sharia governance mempengaruhi minat nasabah untuk berinvestasi pada bank syariah yang bersangkutan.

$\mathbf{H}_{4}$ : Islamic corporate governance berpengaruh secara signifikan terhadap dana pihak ketiga pada bank umum syariah di Indonesia.

\section{METODE}

Populasi dalam penelitian ini adalah seluruh Bank Umum Syariah (BUS) yang terdaftar di Bank Indonesia dari tahun 2014 hingga tahun 2018. Adapun teknik pengambilan sampel menggunakan metode pemilihan sampel bertujuan (purposive sampling) yaitu teknik pengambilan sampel dengan menggunakan kriteria tertentu. Kriteria tersebut yaitu: Bank Umum Syariah (BUS) yang terdaftar di Bank Indonesia secara berturut-turut dari tahun 2014 hingga tahun 2018, mempublikasikan laporan keuangan tahunan dalam website resminya, mempublikasikan laporan pelaksanaan Good Corporate Governance tahunan dalam website resminya, dan mengungkapkan datadata yang berkaitan dengan variabel penelitian secara lengkap selama periode 20142018. Berdasarkan kriteria tersebut diperoleh 8 bank umum syariah yang meliputi: BCA Syariah, Bank Syariah Mega Indonesia, Bank Syariah Mandiri, Bank Muamalat Indonesia, BNI Syariah, Bank Victoria Syariah, BRI Syariah, dan BJB Syariah. Variabel dependen yang digunakan pada penelitian ini adalah dana pihak ketiga. Sedangkan variabel independennya adalah sharia compliance dengan proksi IsIR, PSR, dan ZPR serta Islamic Corporate Governance (ICG).

Metode yang digunakan dalam penelitian ini adalah kuantitatif dengan analisis data menggunakan analisis regresi data panel dan diolah menggunakan E-views 10. Regresi data panel merupakan teknik regresi yang menggabungkan data runtut waktu (time series) dengan data silang (cross section). Metode estimasi model regresi data panel dapat dilakukan melalui tiga pendekatan, antara lain: yaitu common effect model (CEM), fixed effect model (FEM), dan random effect model (REM). Menurut (Ratmono, 2013) untuk memilih model terbaik dalam mengestimasi data panel terdapat tiga cara yaitu uji Chow, uji Hausman dan uji Langrage Multiplier (LM). Uji Cow bertujuan untuk memilih antara common effect model (CEM) atau fixed effect model (FEM) yang paling baik untuk digunakan dalam penelitian. Uji Hausman bertujuan untuk memilih model fixed effect model (FEM) atau random effect (REM) yang paling tepat digunakan dalam 
penelitian. Sedangkan Uji LM untuk mengetahui apakah model random effect model (REM) lebih baik dari pada metode commont effect model (CEM). Uji Asumsi klasik yang harus dipenuhi dalam regresi data panel yaitu uji normalitas, uji multikolinieritas, uji autokorelasi dan uji heterokedastisitas. Uji hipotesis dan analisis data panel terdiri dari uji F, uji T, dan uji koefisien determinasi. Berikut adalah model regresi data panel yang digunakan:

$$
\text { In } Y i=\beta o+\beta 1 \operatorname{In} X i+\beta 2 \operatorname{In} X 2+\beta 3 \operatorname{In} X 3+\beta 4 \operatorname{In} X 4+e i t
$$

Keterangan:

Y : Return on Asset (ROA)

Bo : Konstanta

$\beta 1,2,3,4$ : Koefisien masing-masing variabel

$\mathrm{X} 1 \quad$ : Islamic Corporate Governance (ICG)

$\mathrm{X} 2 \quad$ : Islamic Income Ratio (IsIR)

X3 : Profit Sharing Ratio (PSR)

X4 : Zakat Performing Ratio (ZPR)

e : Error

\section{HASIL DAN PEMBAHASAN}

Berdasarkan hasil uji normalitas diperoleh nilai dari J-B test sebesar 2.117682 dan probabilitas sebesar 0.346857 dimana nilai tersebut lebih besar dari 0,05 atau 5\% maka data pada penelitian ini terdistribusi normal. Untuk uji multikolinearitas diperoleh nilai dari setiap variabel tidak ada yang lebih dari $0.90(<90)$. Ini berarti tidak terjadi masalah multikolinieritas pada penelitian ini.

Hasil uji heteroskedastisitas diperoleh nilai $O b s^{*} R$-Square sebesar 3.871948, maka pada penelitian ini tidak terjadi heteroskedastisitas. Berdasarkan hasil uji autokorelasi dengan menggunakan uji Breusch Godfrey menunjukan nilai Obs*R-squared sebesar 9.099835, artinya penelitian ini terbebas dari masalah autokorelasi dan layak untuk dilanjutkan ke tahap analisis selanjutnya.

Berdasarkan hasil uji chow diperoleh nilai probabilitas Cross-section F dan Crosssection Chi-Square masing-masing sebesar 0.0001 dan 0.0000. Sehingga metode terbaik yang didapatkan dari uji Chow adalah Fixed Effect Model.

Untuk hasil uji Hausman didapatkan nilai probabilitas Cross-section random adalah 0.2503. Maka metode terbaik yang didapatkan dari uji Hausman adalah Random Effect Model.

Berdasarkan Uji Langrage Multiplier (Uji LM) didapatkan nilai cross-section BreuschPagan adalah 0.2023. Jadi metode terbaik yang didapatkan dari Uji Langrage Multiplier (Uji LM) adalah Common Effect Model. Sehingga dapat disimpulkan bahwa model terbaik yang terpilih untuk penelitian ini adalah Common Effect Model (CEM). Hasil ini nantinya akan menjadi hasil terakhir dari setiap pengujian pemilihan yang ada.

Berikut ini ditampilkan hasil uji common effect model yang dilakukan: 
Tabel 1 Hasil Uji Common Effect Model

\begin{tabular}{ccccc}
\hline Variable & Coefficient & Std. Error & t-Statistic & Prob. \\
\hline ISIR & -553.4857 & 603.9113 & -0.916502 & 0.3657 \\
PSR & -4.187040 & 1.370247 & -3.055684 & 0.0043 \\
ZPR & -2.625329 & 3.414792 & -0.768811 & 0.4472 \\
ICG & 2.075924 & 0.597336 & 3.475302 & 0.0014 \\
C & 564.2132 & 603.9206 & 0.934251 & 0.3566 \\
\hline R-squared & & 0.327687 & Mean dependent var & 12.93078 \\
Adjusted R-squared & 0.250851 & S.D. dependent var & 2.941405 \\
S.E. of regression & 2.545886 & Akaike info criterion & 4.823303 \\
Sum squared resid & 226.8537 & Schwarz criterion & 5.034413 \\
Log likelihood & -91.46606 & Hannan-Quinn criter. & 4.899634 \\
F-statistic & 4.264770 & Durbin-Watson stat & 0.730504 \\
Prob (F-statistic) & 0.006469 & & \\
\hline
\end{tabular}

Sumber: Data yang diolah

Pada hasil uji pemilihan model, model yang digunakan dalam penelitian ini adalah Common Effect Model (CEM). Berdasarkan tabel 1 hasil uji Common Effect Model didapatkan persamaan sebagai berikut:

$Y=(564.2132)+(-553.4857) X_{1}+(-4.187040) X_{2}+(-2.625329) X_{3}+(2.075924) X_{4}$

Keterangan:

$\mathrm{Y}=\mathrm{DPK}$

$\mathrm{X}_{1}=$ Islamic Income Ratio (IsIR)

$\mathrm{X}_{2}=$ Profit Sharing Ratio (PSR)

$\mathrm{X}_{3}=$ Zakat Performing Ratio (ZPR)

$\mathrm{X}_{4}=$ Islamic Corporate Governance (ICG)

Sementara itu, hasil uji statistik disajikan pada tabel berikut:

Tabel 2 Uji Statistik F (Simultan)

\begin{tabular}{cc}
\hline Uraian & Nilai \\
\hline R-Squared & 0.327687 \\
Adjusted R-Squared & 0.250851 \\
Prob (F-statistic) & 0.006469 \\
\hline
\end{tabular}

Sumber: Data yang diolah

Hasil uji F pada tabel 2 menunjukkan nilai F-Statistic sebesar 0.006469 dengan angka probabilitas f-statistic lebih kecil dari $0.05(<5 \%)$ yang berarti bahwa semua variabel 
independen yaitu Islamic Income Ratio (ISIR), Profit Sharing Ratio (PSR), Zakat Performing Ratio (ZPR), dan Islamic Corporate Governance (ICG) berpengaruh secara bersama-sama atau secara simultan terhadap Dana Pihak Ketiga (DPK). Dimana variabel independen tersebut mampu menjelaskan sebesar 33\% dari variabel dependennya.

Pengujian parsial disajikan pada tabel berikut:

Tabel 3 Hasil Uji t (Parsial)

\begin{tabular}{ccccc}
\hline Variabel & Coefficient & T-Statistic & Prob & Keterangan \\
\hline C & 564.2132 & 0.934251 & - & - \\
IsIR & -553.4857 & -0.916502 & 0.3657 & Tidak Signifikan \\
PSR & -4.187040 & -3.055684 & 0.0043 & Signifikan \\
ZPR & -2.625329 & -0.768811 & 0.4472 & Tidak Signifikan \\
ICG & 2.075924 & 3.475302 & 0.0014 & Signifikan \\
\hline
\end{tabular}

Sumber: Data yang diolah

Berdasarkan tabel 3 dari hasil uji common effect model terdapat dua variabel yang berpengaruh terhadap dana pihak ketiga yaitu profit sharing ratio dan Islamic corporate governance. Sedangkan variabel Islamic income ratio dan zakat performing ratio tidak berpengaruh terhadap dana pihak ketiga.

\section{Pengaruh Islamic Income Ratio (IsIR) Terhadap Dana Pihak Ketiga}

Berdasarkan tabel 3 hasil uji t-statistik pada variabel Islamic Income Ratio (IsIR) menunjukkan nilai sebesar 0.3657 dimana angka tersebut lebih besar dari nilai signifikan sebesar 5\% (> 0.05), maka hipotesis pertama $\left(\mathrm{H}_{1}\right)$ ditolak. Hal tersebut berarti variabel Islamic Income Ratio tidak memiliki pengaruh secara signifikan ataupun pengaruh secara individual terhadap Dana Pihak Ketiga (variabel dependen).

Hal tersebut dikarenakan Islamic Income Ratio merupakan rasio yang membandingkan antara pendapatan halal dengan seluruh total pendapatan yang diperoleh oleh bank syariah (pendapatan halal dan non halal). Berdasarkan penelitian yang dilakukan (Pudyastuti, 2018) menyebutkan bahwa perbankan syariah memperoleh pendapatan non halal dari kegiatan konvensional yang kemudian disalurkan sebagai dana kebajikan yang disalurkan ke lembaga lain. Pada catatan atas laporan keuangan disebutkan bahwa dana kebajikan pada bank syariah merupakan penerimaan denda nasabah pembiayaan dan jasa giro dari bank konvensional. Oleh karena itu apabila terjadi peningkatan terhadap islamic income tidak selalu meningkatkan jumlah dana pihak ketiga pada bank umum syariah. Sehingga variabel Islamic Income Ratio (IsIR) tidak berpengaruh secara signifikan terhadap Dana Pihak Ketiga. 


\section{Pengaruh Profit Sharing Ratio (PSR) Terhadap Dana Pihak Ketiga}

Berdasarkan hasil pengolahan data pada tabel 3 bahwa variabel Profit Sharing Ratio (PSR) diperoleh nilai sebesar 0.0043 dimana nilai tersebut lebih kecil dibandingkan dengan nilai signifikan sebesar 5\% $(<0.05)$ maka hipotesis kedua $\left(\mathrm{H}_{2}\right)$ diterima. Maka variabel Profit Sharing Ratio memiliki pengaruh secara signifikan ataupun pengaruh secara individual terhadap Dana Pihak Ketiga (variabel dependen).

Hal tersebut dikarenakan rasio bagi hasil merupakan rasio yang membandingkan antara pembiayaan mudharabah dan musyarakah dengan seluruh total pembiayaan yang ada pada bank syariah tersebut. Oleh karena itu jika tingkat atau rasio bagi hasil mengalami peningkatan maka hal tersebut juga mendorong terjadinya peningkatan pada jumlah Dana Pihak Ketiga. Karena para investor akan tertarik untuk menginvestasikan dananya melihat tingkat bagi hasil yang cenderung selalu mengalami peningkatan.

Hasil penelitian ini sesuai dengan penelitian yang dilakukan oleh (Fitrisia, 2016) yang menyatakan bahwa bagi hasil berpengaruh secara signifikan terhadap jumlah Dana Pihak Ketiga pada bank umum syariah. Karena bagi hasil merupakan bentuk return dari kontrak investasi para nasabah (Karim, 2013). Bagi investor tujuan utama investasi adalah untuk mendapatkan keuntungan, sehingga dalam menempatkan dana di bank syariah nasabah cenderung memperhatikan keuntungan yang akan diperolehnya. Sesuai dengan penelitian yang dilakukan oleh Haron dan Norafifah (2000), return yang diberikan pada DPK berhubungan positif terhadap jumlah DPK bank syariah. Sehingga dapat disimpulkan bahwa bagi hasil berpengaruh secara signifikan terhadap jumlah Dana Pihak Ketiga.

\section{Pengaruh Zakat Performing Ratio (ZPR) Terhadap Dana Pihak Ketiga}

Berdasarkan hasil pengolahan data yang terdapat pada tabel 3 bahwa variabel Zakat Performing Ratio (ZPR) menunjukkan nilai sebesar 0.4472 dimana angka tersebut lebih besar dari nilai signifikan sebesar 5\% (> 0.05), maka hipotesis ketiga $\left(\mathrm{H}_{3}\right)$ ditolak. Hal tersebut berarti variabel Zakat Performing Ratio (ZPR) tidak memiliki pengaruh secara signifikan terhadap Dana Pihak Ketiga (variabel dependen).

Menurut (BAZNAS, 2019) zakat merupakan kewajiban yang harus dipenuhi oleh setiap institusi keuangan syariah. Sehingga setiap perusahaan yang melakukan kegiatan operasionalnya berdasarkan prinsip syariah wajib mengeluarkan zakat perusahaan sebagaimana yang diatur dalam Undang-Undang No. 38 Tahun 1999. Selain itu, pada penelitian yang dilakukan oleh (Raharjo, 2014) menyebutkan bahwa zakat merupakan salah satu tanggung jawab sosial yang harus dilaksanakan oleh setiap lembaga keuangan syariah. Dimana dengan terlaksananya tanggung jawab tersebut, hal ini dianggap cukup efektif sebagai promotion tools dan public relation. Sehingga dengan dipenuhinya penyaluran zakat oleh suatu bank syariah, maka hal tersebut dapat meningkatkan minat nasabah untuk menyimpan dananya pada bank syariah.

Namun berdasarkan data yang telah penulis olah, memperlihatkan bahwa rasio kinerja zakat tidak memiliki pengaruh terhadap Dana Pihak Ketiga. Hal tersebut karena zakat dihitung sebagai pengurang laba sebelum pajak untuk menghasilkan laba bersih 
setelah zakat. Karena pelaporan dana zakat disajikan terpisah dengan pendapatan dan beban yang diperoleh bank syariah. Oleh karena itu apabila terjadi peningkatan terhadap rasio kinerja zakat tidak selalu meningkatkan jumlah dana pihak ketiga pada bank umum syariah. Sehingga variabel Zakat Performing Ratio (ZPR) tidak berpengaruh secara signifikan terhadap Dana Pihak Ketiga.

\section{Pengaruh Islamic Corporate Governance (ICG) Terhadap Dana Pihak Ketiga}

Berdasarkan nilai probabilitas yang terdapat pada tabel 3 bahwa variabel Islamic Corporate Governance (ICG) sebesar 0.0014. Dimana nilai tersebut lebih kecil dibandingkan dengan nilai signifikan sebesar 5\% $(<0.05)$ maka hipotesis keempat $\left(\mathrm{H}_{4}\right)$ diterima. Hal tersebut berarti variabel Islamic Corporate Governance memiliki pengaruh secara signifikan terhadap Dana Pihak Ketiga (variabel dependen).

Hasil penelitian ini sejalan dengan penelitian yang dilakukan oleh (Winny Widialoka, 2016) yang menyatakan bahwa good corporate governance berpengaruh secara signifikan terhadap jumlah Dana Pihak Ketiga. Islamic Corporate Governance (ICG) merupakan tata kelola perusahaan dengan menggunakan prinsip-prinsip Syariah. Dimana dijelaskan bahwa pada bank syariah, implementasi dari Islamic Corporate Governance (ICG) terdapat pada Dewan Pengawas Syariah (DPS). Dimana semakin baik peran Dewan Pengawas Syariah (DPS) maka akan memberikan jaminan bahwa bank tersebut telah menjalankan prinsip syariah sesuai dengan kaidah dan peraturan yang berlaku (Nurdin, 2017).

Jadi, dengan terlaksananya Islamic Corporate Governance (ICG) pada bank umum syariah maka hal tersebut juga akan meningkatkan kepercayaan masyarakat untuk menginvestasikan dananya pada bank syariah sehingga dapat meningkatkan jumlah investor (dana pihak ketiga). Nasabah merasa yakin dan percaya bahwa bank yang bersangkutan telah menjalankan prinsip-prinsip syariah dengan baik.

\section{SIMPULAN}

Berdasarkan hasil penelitian dapat disimpulkan bahwa variabel Profit Sharing Ratio (PSR) dan Islamic Corporate Governance (ICG) berpengaruh secara signifikan terhadap Dana Pihak Ketiga. Sedangkan variabel Islamic Income Ratio (IsIR) dan Zakat Performance Ratio (ZPR) tidak berpengaruh secara signifikan terhadap Dana Pihak Ketiga. Kemudian secara simultan seluruh variabel independen berupa Islamic Income Ratio (IsIR), Profit Sharing Ratio (PSR), Zakat Performing Ratio (ZPR), dan Islamic Corporate Governance (ICG) berpengaruh secara signifikan terhadap Dana Pihak Ketiga pada Bank Umum Syariah. Dengan adanya pengaruh variabel profit sharing ratio dan Islamic corporate governance maka diharapkan lembaga perbankan syariah lebih memperhatikan tata kelola agar sesuai dengan prinsip syariah yang berlaku. Sehingga dapat meningkatkan kepercayaan dan loyalitas nasabah untuk berinvestasi di bank syariah. Selain itu bank syariah juga dapat memperbanyak penyaluran dana pada produk pembiayaan bagi hasil (mudharabah dan musyarakah), karena ini menjadi ciri dari bank syariah sebagai bank dengan prinsip bagi hasil. Selain itu juga dapat meningkatkan dana pihak ketiga yang diperoleh oleh bank syariah itu sendiri. 


\section{PUSTAKA ACUAN}

Asrori. (2014). Implementasi Islamic Corporate Governance Dan Implikasinya Terhadap Kinerja Bank Syariah. Jurnal Dinamika Akuntansi, 6.

BAZNAS. (2019). Rasio Keuangan Organisasi Pengelola Zakat Teori dan Konsep. Jakarta: Pusat Kajian Strategis Badan Amil Zakat Nasional.

Fitrisia, W. M. (2016). Analisis Faktor-Faktor Yang Mempengaruhi Jumlah Dana Pihak Ketiga Pada Bank Umum Syariah Di Indonesia. Jurnal Ekonomi Syariah Teori dan Terapan Vol. 3, 10.

Hameed. (2004). Alternative Disclosure and Performances Measures For Islamic Banks . Second Confrence on Administrative Sciences: Meeting The Challenges of The Globalization Age, King Fahd University of Petroleum and Minerals, Dhahran, Saudi Arabia .

Junusi, R. E. (2012). Implementasi Syariah Governance Serta Implikasinya Terhadap Reputasi dan Kepercayaan Bank Syariah. Al-Tahrir Vol. 12 No. 1, -.

Karim, A. A. (2007). Bank Islam: Analisis Fiqih dan Keuangan. Jakarta: PT Rajagrafindo Persada.

Karim, A. A. (2013). Bank Islam Analisis Fiqih dan Keuangan Edisi Kelima. Jakarta: PT Rajagrafindo Persada.

Maradita. (2014). Karakteristik Good Corporate Governance pada Bank Syariah dan Bank Konvensional. Yuridika Vol. 29, 2.

Mulazid, A. S. (2016). Pelaksanaan Sharia Compliance Pada Bank Syariah (Studi Kasus Pada Bank Syariah Mandiri, Jakarta). Madania, Vol.20 No.1.

Nurdin, M. Y. (2017). Pengaruh Sharia Compliance dan Islamic Corporate Governance Terhadap Kinerja Keuangan Bank Umum Syariah di Indonesia (Studi Kasus Perbankan Syariah di Indonesia 2013-207. Prosiding Manajemen.

Pudyastuti, L. W. (2018). Pengaruh Islamicity Performance Index dan Financing to Deposit Ratio (FDR) Terhadap Kinerja Keuangan Perbankan Syariah di Indonesia. Jurnal Manajemen Bisnis Indonesia.

Raharjo, A. d. (2014). Pengaruh Alokasi Dana Zakat Terhadap Kinerja Keuangan Perbankan Syariah. e-journal UPS Tegal.

Rifqi Muhammad, d. (2019). Analisis Pengaruh Syaria Compliance dan Islamic Corporate Governance Terhadap Tindakan Fraud (Studi Empirik pada BUS di Indonesia 20132017). Iqtishadia, Jurnal Ekonomi dan Perbankan Syariah Vol.6 No.1.

Rini, H. N. (2016). Sharia Compliance, Islamic Corporate Governance dan Fraud Pada Bank Syariah. Jurnal Akuntansi dan Keuangan Islam Vol.4.

Umar, F. d. (2012). Bank Syariah Di Indonesia: Ketaatan Pada Prinsip-Prinsip Syariah dan Kesehatan Finansial . Proccedings of Conference In Business, Accounting and Management (CBAM) Vol. 1, 245.

Umiyati, d. (2020). Islamic Corporate Governance and Sharia Compliance on Financial Performance Sharia Bank in Indonesia. Al-Iqhtisad Volume 12 No. 1. 
Wardayati, S. M. (2011). Implikasi Sharia Governance Terhadap Reputasi dan Kepercayaan Bank Syariah. Walisongo Vol. 19 No. 1.

Winny Widialoka, d. (2016). Analisis Pengaruh Kepatuhan Syariah (Sharia Compliance) Terhadap Dana Pihak Ketiga Pada Bank Umum Syariah Di Indonesia Periode Tahun 2010-2015. Prosiding Keuangan dan Perbankan Syariah Gel. 2, 674.

Yaya, F. B. (2016). Risiko Likuiditas pada Perbankan Konvensional dan Syariah Di Indonesia. Jurnal Riset Akuntansi dan Bisnis Vol. 16, 6.

Yaya, R. (2014). Akuntansi Perbankan Syariah. Jakarta: Salemba Empat.

Yusnita, R. (2019). Analisis Kinerja Bank Umum Syariah Dengan Menggunakan Pendekatan Islamicity Performance Index Periode Tahun 2012-2016. Jurnal Islamic Banking and Finance, 2. 